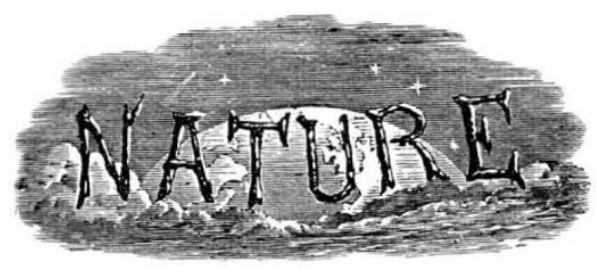

SATURDAY, OCTOBER I4, I933

No. $3337 \quad=\quad$ Vol. 1

Science for Citizenship

History of Elementary Mathematics. By T. L. H.

Plant Analysis. By F. F. A.

Archæology and the Greek Heroic Legends

Determinations of Gravity at Sea. By S. C.

Short Reviews

The 74-inch Reflecting Telescope for the University of Toronto

Insect Transmission of Spike-Disease :

$\mathrm{X}$-Ray Analysis of Fibres. By W. T. A.

News and Views

Letters to the Editor :

Remarkable Optical Properties of the Alkali

Metals.-Dr. R. de L. Kronig -D
Solar Activity and Cosmic Rays.-Prof. Victor

F. Hess and R. Steinmaurer Fields at Low

Temperatures.-Dr. K. Mendelssohn at Low

Structure of Emulsoid Sol Particles and their

Hydration Film.--Dr. N. H. Kolkmeijer and

Dr. J. C. L. Favejee

Relation between Van der Waals' and Activated Adsorption on Chromium Oxide Gel.--John Howard

Photo-activity of Bichromated Colloids. $-\dot{H}$. Mills Cartwright and Hywel Murrell .

Decomposition of Specific Bacterial Polysaccharides by a Species of Myxobacterium.W. T. J. Morgan and A. C. Thaysen.

Method for the Separation of Enzymes from their Mixtures.- M. Sreenivasaya and N Keshava Iyengar

A Reducing Substance in Tumours.-Dr. Leslie J. Harris . . .

Association of Hippoboscids with íce.-

Gordon B. Thompson
Creeper and Single-Comb Linkage in Fowl.-

Dr. Walter Landauer

Co-operation in Science.-Allan Gomme :

Research Items.

Estrogenic Hormones

Cattle Research in Northern Queensland.

A. C. D. R.

Panstereoscopic Photography

Organisation as a Technical Problem

Cosmic Rays and Nuclear Physics

University and Educational Intelligence

Calendar of Nature Topics.

Societies and Academies

Forthcoming Events

Official Publications Received

Editorial and Publishing Offices :

MACMILLAN \& CO., LTD

ST. MARTIN'S STREET, LÖNDON, W.C.2

Telephone Number: WHITEHALL 883 I

Telegraphic Address : PHUSIS, LESQUARE, LONDON

Advertisements should be addressed to

T. G. Scott \& Son, Ltd., 63 Ludgate Hill, London, E.C.4 Telephone Number: City $42 \mathrm{II}$

\section{Science for Citizenship}

ALL who are concerned about the gathering economic distresses of our time will welcome the growing conviction of the world of science, as evinced at the Leicester meeting of the British Association, that scientific men have a social mission over and above the disinterested investigation of Nature, and that it is impossible completely to detach the process which we call science from the uses to which its discoveries are put in the life of our race.

If this world were simply a technical problem, something far more radical than the advisory activities now proposed to be taken up by the Association would be possible. Those aspects of government which depend simply on exact knowledge could undoubtedly be better handled by technicians and men of science than by politicians. But the problem is not merely technical. What has to be organised is not the interaction of cams and cogs and levers, nor even the more complex dynamics of chemical and biological systems. The salvation of our world from the chaos which threatens it is a problem of the co-operation of human beings. That co-operation must admittedly be based on exact knowledge and informed with the spirit and temper of science ; but it must also, if it is to be happy and fruitful, awaken the sympathy and understanding of the lay public whose daily lives it will involve.

It follows that the scientific world must conduct, pari passu with its expert discussion of social problems, a campaign of publicity and education more ambitious than it has ever attempted before. It must seek to popularise, not principally its concrete proposals for the scientific control of civilisation, but the knowledge and method from which those proposals derive their force. Many scientific workers will look askance on such a project, rightly perceiving that the delicacy and precision of their intellectual technique is illadapted to the rough handling of the marketplace. But while it is true that science cannot be put on the hoardings like the catchwords of a political party, or conveyed in an atmosphere of emotionalism like the tenets of a popular religion, it does not pass the wit of man to invent modes of presentation whereby a broad understanding of scientific knowledge can be imparted to the man in the street. Moreover, since it is becoming painfully clear that the scientific man lives in the social world and is himself 
peculiarly vulnerable to its misfortunes, the sort of professional pride which will not explain itself to ordinary folk is a pride which goes deservedly before a fall.

It is therefore very appropriate that the Educational Science Section of the British Association should have received at Leicester a report from its Committee on the position of "Science Teaching in Adult Education Classes"*. The world of science is to-day increasingly able to obtain, and should deliberately seek, the most varied forms of publicity, including isolated popular lectures, newspaper articles, 'feature' films for general exhibition, radio talks and attractively written popular books. The serious study of science by non-professional adult students, continued over a series of meetings under the guidance of a tutor or lecturer of adequate knowledge and ability, must play an increasingly important part in the formation of the public mind. Men and women trained in such classes, though they be necessarily a tiny minority, can become by their vivid consciousness of the relevance of scientific knowledge to the happenings of the economic world the catalysts of that scientific revolution the need for which grows ever more pressing.

The presentation of science to non-professional adult students necessarily differs in its angle of approach from the instruction of students destined for some branch of the scientific profession. Its aim is to fit men for life in a civilisation founded on science, rather than to make original investigators or technical specialists. There will therefore be less insistence on the minutix of logical and experimental technique, and more on the manifold contacts of science with life. People, as the Committee's report suggests, are more interested in conclusions and their social and philosophical bearings than in the more recondite details of specialised research; and in the event that the scientific purist should urge that such a study is not science at all but something else, the reply is open that, science or not, it is a popular interest of the greatest importance to the scientific profession.

The traditional way of relating science to life is that generically represented by the caption, 'science and common things'. The worker in metal can be interested in the new knowledge of crystal structure as it relates to alloys or the heat

* Report of Committee appointed to consider the position of Science Teaching in Adult Education Classes, and to suggest possible means of promoting through them closer contact between Scientific Achievement and Social Development. (British Association, Burlington
House, London, W.1.) treatment of metals. The worker in the chemical industry can be approached through the transformations which he sees going on in the works. The motorist or the wireless enthusiast can be led to science through the gateway of his very technical hobby. The agricultural labourer or farmer can find scientific interest in his daily experience of plant and animal life, of fertilisers and dressings. Even the housewife, practitioner of the most primitive of modem callings, can learn to discover unsuspected scientific truths in the washtub, the oven or the child's top.

There is, however, another and still more important avenue, which is suited both to the present temper of the scientific world and to the enduring common interest shared by most intelligent working people. Few who have not direct contact with working-class movements can realise how large a part 'politics' - in the broadest. sense-plays in the intellectual development of the worker. The intelligent workman naturally gravitates to the activity of his trade union, his co-operative society or his political association; and his whole vocabulary and outlook bear the impress of this dominant interest. It plays in his life an analogous rôle to that of the university in more fortunate social strata. It is his avenue to the mastery of life. It follows that the most appropriate way of presenting science to that vast majority of our population which makes up the working-class is from the angle of its effects on social life and the hopes and dangers for common folk which scientific discovery brings in its train.

This predilection of intelligent working-people affords a striking opportunity to the missionaries of science at the present time. The technique of presentation which those missionaries must employ offers, however, a problem of its own. The Report to which reference has been made emphasises the apparent lack of good tutors and lecturers able to present science acceptably to working-folk. That task demands, not only a wide and sound knowledge of science combined with the power of lucid exposition and happy illustration which the great masters of popularisation have possessed, but also a living appreciation of the social interests of the student. It demands also the rather unusual ability to relate social aspiration, not merely to scientific results, but also to that objective temper of thought whereby those results have been so abundantly achieved.

Men possessed of the aptitudes of knowledge and temperament for such work are comparatively 
rare; nevertheless they are probably available in larger numbers than the Report suggests. The problem is to attract them from pursuits which at present seem to offer greater prospect of advancement. The young scientific man who has a bent for adult teaching finds at present that though he may make or supplement a living by such work, yet it is through research that his way to professional success lies. Adult education, however fascinating, does not yet offer the man of science a career. If, therefore, the scientific world wishes to make effective the educational aspect of its increasing social project, it must create a new branch of the profession of science to concerm itself principally, and not merely incidentally, with such work. There must be a career open to men of talent in the interpretation of science as well as to those whose bent is original investigation.

There is a type of science student who would rather talk about research than pursue it. It is a type which has been rather neglected in the past, since the scientific man feels with good reason that the life of investigation is pre-eminently worthy of respect. Probably, however, at the present time, the interpreter can do for science something which is even more vitally necessary than the creative work of original inquiry. It would perhaps be well if scientific workers made in the near future an unprecedented attempt to organise the propagandist and interpretative side of science, and to see their problem of publicity as a whole in which the adult educational class has its essential place.

If a deliberate effort were made to link up the teaching of science to adults with the whole business of scientific journalism and writing, scientific broadcasting and the making of scientific films, and the organisation of adequate publicity for science, it should be possible to offer to the young science student with a gift for writing and talking a career which would be well worthy of his consideration.

The House of Saloman was conceived as an organisation of savants; but it was the dream of a man greater himself as an interpreter than as an original investigator. Those who inherit his great tradition could not more fitly honour his memory than by the creation of a body of professional missionaries and teachers who would make straight the pathway of the scientific State in a world threatened with dissolution and chaos.

L. A. F.

\section{History of Elementary Mathematics}

Geschichte der Elementar-Mathematik in systematischer Darstellung: mit besonderer Berücksichtigung der Fachwörter. Von Dr. Johannes Tropfke. Band 2: Allgemeine Arithmetik. Dritte verbesserte und vermehrte Auflage. Pp. iv +266. (Berlin und Leipzig: Walter de Gruyter und Co., 1933.) 12 gold marks.

THE first volume of this third edition of Tropfke's history of elementary mathematics appeared towards the end of 1930 ; the second, now under notice, follows at an interval of two and a half years. At this rate of progress, it will be a long time before we have the seventh volume which is to contain the new and complete indexes to the whole work. The absence of the indexes in the meantime will be a serious inconvenience; for those, however, who possess the second edition this will be mitigated by the fact that, so far as the matter in that edition is concerned, the old indexes will serve, because the editor gives at the end of each volume tables showing the correspondence of pages in the two editions and of the relative footnotes.

The number of pages in vol. 2 has increased in this edition from 222 to 266 and the number of footnotes from 1,157 to 1,461 ! Many of the new references are to works and papers so recent as 1932, so that the two and a half years which have elapsed since the issue of vol. 1 have yielded much that was worth waiting for. The book cannot be too strongly recommended as a really up-to-date encyclopædia of the history of elementary mathematics. The editor had the assistance of Heinrich Wieleitner, the well-known historian of mathematics, until his death in 1931, and his young co-workers, Kurt Vogel and J. E. Hofmann, gave further assistance while the book was in the press.

In accordance with the original plan, vol. 2 is entitled "Allgemeine Arithmetik" and deals with (a) algebraic notations and their gradual development, $(b)$ the name 'Algebra', $(c)$ the development of the notion of number (including irrational, negative, and complex numbers), (d) algebraical operations, (e) the history of logarithms, which itself covers nearly sixty pages.

Specially noteworthy are the additions made in the domain of ancient mathematics. Account is taken (1) of a number of Greek papyri recently investigated and published (see the long note on page 5), (2) of the latest researches into Babylonian 